\title{
Entrepreneurship in the rural context: Practical reflection on success and innovation
}

\author{
Vukosi Autis Mkhavele ${ }^{1^{*}}$ and Thembie Ntshakala ${ }^{2}$ \\ ${ }^{1}$ Regent Business School, Johannesburg, South Africa. \\ ${ }^{2}$ Director, Polokwane Municipality, Financial and Fiscal Commission (FFC), South Africa.
}

Received 21 July, 2018; Accepted 8 October, 2018

\begin{abstract}
Given the important role that entrepreneurship plays in the economy, it is desirable that entrepreneurs succeed. However, there is a noticeable trend of rural entrepreneurs migrating to urban areas. This study aims to ascertain the factors that contribute to entrepreneurial success. Using quantitative methods fifty respondents participated and data was collected using questionnaires. The collected data was analysed and presented both descriptively and inferentially. The study found that the majority of entrepreneurs agree that factors that positively impact innovation include good customer service; hard work; social skills; a good product at a competitive price and maintenance of accurate records. Appropriate training for entrepreneurs also helps to avoid mistakes made by other entrepreneurs. The study, therefore, recommends that government as well as the private sector offer greater support to entrepreneurs.
\end{abstract}

Key words: Entrepreneurs, finance, performance.

\section{INTRODUCTION}

Entrepreneurship contributes greatly to the economy of the country (Tomaa et al., 2014: 437). The opportunity to create wealth and being one's own boss are factors that attract many to entrepreneurship. However, the number of entrepreneurs who actually become successful is low. In a country like South Africa, with an unemployment rate of $26.5 \%$, entrepreneurship is essential (Stats SA, 2017; 9).

Against this backdrop, the government aims to implement policies, strategies and programmes in order to create an enabling environment for small businesses. The Limpopo Province is one of South Africa's most deprived areas and its personal income per capita is only
38 percent of South Africa's average, the lowest of all nine provinces (Smith, 2016). According to the Provincial Review 2016, the province has experienced faster than average economic growth in the agriculture, power, tourism and mining sectors. The continuing growth rate economy of Limpopo Province by far surpasses the national one, at an average of 4 percent gross domestic product per region (Provincial Review, 2016). This contribution has had a profound impact in terms of the economic growth and development of the entire country. It is against this background that the researcher sought to investigate factors that impinge on entrepreneurial success and the effect of these factors on innovation.

*Corresponding author. E-mail: autismkhavele@yahoo.com.

Author(s) agree that this article remain permanently open access under the terms of the Creative Commons Attribution License 4.0 International License 


\section{Significance of the study}

As a direct effect of globalisation, entrepreneurial enterprises face increasing pressure from competition across the world. In line with the changing demand of customers worldwide, it becomes apparent that entrepreneurs face increasing difficulty to maintain and improve their business performance in time. They are often not able to dynamically manage these pressures (Kraus et al., 2012). One way to manage this is to invest in entrepreneurial activities as a strategy to achieve sustainable competitive advantage in today's complex global economy (lyigun, 2015).

Entrepreneurial organisations involve risk-taking and are innovative and proactive in their decision-making styles, practices and methods. This tendency of behaviour is described as entrepreneurial orientation (EO), which is considered an essential attribute of high performing firms (Covin and Wales, 2011). At the same time, EO is also an important resource that facilitates a firm to outperform rivals and yield marketplace positions of competitive advantage (Amiri and Marimaei, 2012: 151). High scores of EO afford firms an opportunity to survive and achieve profitability, market share growth and differentiation (Wiklund and Shepherd, 2003; Paco et al., 2011). With their proactive approach, entrepreneurial firms can anticipate changes of markets and needs of customers. They can also forge new market segments, and introduce new products and services to respond ahead of the competition (Amiri and Marimaei, 2012: 153). In addition, SMEs with higher risk-taking orientation that engage in resources can gain a great and higher investment return (Ngek and van Aardt, 2013).

\section{LITERATURE REVIEW}

The purpose of this literature review is to relate established ideas and knowledge to factors that affect entrepreneurial success and to determine how this influences innovation. This is achieved by reporting on entrepreneurial success and innovation as well as on the challenges that rural entrepreneurs face.

\section{Definition of an entrepreneur}

An entrepreneur is an individual who notices opportunities and then determines how to mobilise the necessary resources to produce new and improved services and goods (Jones and George, 2011: 235). Amiri and Marimaei (2012:152) define an entrepreneur as someone who "perceives a vision, commits himself to that vision, and almost single-handedly carries the vision to its successful implementation". This definition encapsulates more than simply someone who recognises and meets a need.

Being entrepreneurial means being associated with entrepreneurship. Entrepreneurship is the managerial process in which there is creation and innovation management (Drucker, 2015). This definition only examines the management side. According to Gries and Naudé (2011: 217), a synthetic definition highlights entrepreneurship as "the resource, process and state of being through and in which individuals utilise positive opportunities in the market by creating and growing new business firms." However, a more acceptable and people-orientated definition outlines entrepreneurship as "involving innovation, development, recognition, seizing opportunities and converting opportunities to marketable ideas while bearing the risk of competition." (Amiri, and Marimaei, 2012: 151).

\section{Characteristics of an entrepreneur}

\section{Need for achievement}

The entrepreneur seeks to establish a sense of achievement for himself and others. This has been positively correlated with business success (Cubico et al., 2010: 427).

\section{Risk taking propensity}

Carland and Carland (2015) highlight that an entrepreneur is one who organises a new venture, manages it, and assumes the associated risk. At times, the entrepreneur will face opportunities that may not look profitable at a particular moment but have potential to be profitable later on. An entrepreneur needs to realise these opportunities. Risk includes not only financial considerations, but also career opportunities and family relations (Carland and Carland, 2015).

\section{Self-confidence}

According to Greathouse (2011), entrepreneurs ought to have this kind of quality as they are expected to possess a sense of self-esteem as well as competence in conjunction with their business affairs. An entrepreneur must believe in his own work. Greathouse further points out that "legitimate entrepreneurial confidence is derived from one's ability to execute, just as a musician gain selfassurance by practicing their instrument". These views are also shared by Asoni (2011) who explains that selfconfidence is necessary in order to increase the probability of owning and managing an organisation, which in turn has an effect on business survival.

\section{Pro-activeness}

In the words of Schillo (2011) pro-activeness is the "characteristic of entrepreneurial actions to anticipate 
future opportunities, both in terms of products or technologies and in terms of markets and consumer demand". Dess et al. (2014) support this as they view pro-activeness as a forward-looking perspective that characterises a marketplace leader with the foresight of seizing opportunities while anticipating future demand. The entrepreneur should always be on the lookout for possible opportunities. The idea of being proactive was central to early economic thinking in the field: the entrepreneur was thought of as someone who would identify opportunities in the marketplace and pursue them proactively (Lumpkin and Dess, 1996). Organisations that comprise pro-activeness are therefore considered as leaders and not followers.

\section{Competitive aggressiveness}

Competitive aggressiveness embraces the "company's way of engaging with its competitors, distinguishing between companies that shy away from direct competition with other companies and those that aggressively pursue their competitors' target markets" (Schillo, 2011). By starting new businesses, entrepreneurs intensify competition for existing businesses. This leads to decreased prices of goods and a wider variety of goods and services for consumers (Kritikos, 2014). Competition is enhanced as it pushes existing or established organisations to improve their performance. Consumers also benefit from this.

\section{Internal locus of control}

"People with an internal locus of control believe that they shape their future outcomes through their own actions" (Kritikos, 2014). Entrepreneurs should, therefore, have an internal locus of control to propel them. People with an external locus of control believe their fate is maintained by external factors (Northouse, 2013: 141). People with an internal locus of control have self-efficacy which is the belief one has about being able to do something successfully. On the other hand, people with an external locus of control consider their behaviours and lives as being controlled by luck or fate (Donatelle, 2011). Having an internal locus of control can help to successfully differentiate between effective and ineffective leaders, managers, and employees.

\section{Leadership}

While leaders are not necessarily entrepreneurs, entrepreneurs are leaders in their own right (EL-Annan, 2013: 151). Jones and George (2011) refer to leadership as the process wherein an individual exerts influence over other people, thereby inspiring, motivating and directing their abilities to help achieve group or organisational goals. Certain leadership styles produce behaviours that are better suited to entrepreneurship. According to Salzarulo and Newman (2012), selfleadership has to do with the knowledge of oneself better and steering oneself towards objectives and better life. Ashenbaum et al. (2012) and Gordon et al. (2008) posit that research recently discovered a significant and positive connection between behaviours displayed by self-leadership and orientation towards entrepreneurship. Transactional leadership refers to the process where a leader and his follower, through the clarification of their role and duties, obtain certain agreed outcomes (Currie, 2008). It differs from transformational leadership in that transformational leadership makes subordinates aware of the importance of their jobs and performance to the organisation (Jones and George, 2011). This implies that both the transactional and transformational leadership styles are highly proactive. The transactional leadership style produces an external drive while the transformational style produces an internal drive (ELAnnan, 2013: 151).

\section{Tolerance for ambiguity}

Tolerance for ambiguity depicts the behaviour of individuals in situations where one has to act when there is lack of clarity or lack of information (Stoycheva, 2010). Ambiguity may be experienced in a range of settings and may be unpredictable. According to Mastura et al. (2009), the manner in which an entrepreneur approaches a situation and administers it, reflects the extent to which he tolerates ambiguity. An entrepreneur who has a high tolerance for ambiguity may find ambiguous situations challenging but will strive to overcome these situations in order to perform well. Past studies reveal that the majority of entrepreneurially-inclined individuals have a higher tolerance for ambiguity than others (Sexton and Bowman, 1985). Individuals who are intolerant of ambiguity may experience a sense of psychological discomfort when they are confronted with an ambiguous situation (Stoycheva, 2010).

\section{Entrepreneurial success}

Success can be defined in many ways. Some studies define success as surviving the first two or three years that a company is in business (Olakitan and Ayobami, 2011: 96). Hornaday and Bunker (1970), for example, typified a successful entrepreneur as an individual who starts a business, builds it up to where no previous business has functioned, and then continues for a period of at least five years to create a profit-making structure. Other studies on entrepreneurial personality (Gatewood et al., 1995) defined success in financial terms. These researchers thus linked the common characteristics found among entrepreneurs to measures like return on 
investment, growth in sales, and profit every year or to the personal income of the manager or owner of the business. "Although many indices might be used as criteria of success, continuity in business is the all persuasive quality" (Hornaday and Bunker, 1970). Nevertheless, statistics about newly founded organisations show that most of them do not survive the first few years (Olakitan and Ayobami, 2011:96).

The current study adopts the definition of Klubeck (2017:190), who suggested that success is defined by the reason for the organisation's existence. Furthermore, there is success in how well the business owner is fulfilling his or her purpose in life, how well they are answering their calling.

\section{Factors that contribute to entrepreneurial success}

\section{Decision-making}

Entrepreneurs have to deal with decision-making opportunities on a daily basis. Decision-making has gone as far as being called the 'backbone of entrepreneurship' (Talebi et al., 2014:59). According to Talebi et al. (2014: 59), all individuals make decisions, but entrepreneurial decision-making is biased. Furthermore, these biased decisions are influenced by many factors. While Brundin and Gustafsson (2013:5) also attest to the biases displayed by entrepreneurs when making decisions, they found that emotions were the main cause of these biases. These biases will ultimately influence how the business is run. Just as decision-making can determine the trajectory of one's life, it can also determine whether an entrepreneur will become successful or not.

\section{Government support}

In its major role in all nations of the world, entrepreneurship contributes to national economies through starting up and running Small and Medium sized Enterprises (SMEs). These enterprises potentially make up to $95 \%$ of the total number of enterprises and provide jobs to more than $60 \%$ of all employees within different countries (Stefanovića et al., 2011: 79). Obaji and Olugu (2014: 110) confirm this. The significance of entrepreneurship to economic development compels the government to continue in facilitating its growth through necessary means (Stefanovića et al., 2011: 79).

Some of the ways the government achieves the abovementioned objectives include enacting entrepreneurfriendly policies (Obaji and Olugu, 2014: 110). Different countries around the world implement some sort of efforts towards entrepreneurship. However, not all of these efforts turn out to be successful, as was the case with Nigeria, due to corruption and other factors (Ihugba, Odii and Njoku, 2014). Furthermore, Friedman (2011) observed contradictory findings about government policy that can be negatively related to entrepreneurship.

\section{Motivation}

Jones and George (2011:400) define motivation as the psychological force determining the direction of a person's behaviour within an organisation, a person's level of effort as well as a level of persistence when faced with obstacles. Everybody has needs to be met, which may explain the reason for motivation at different stages. It is important to know the motivational factors behind entrepreneurs because it may explain why certain entrepreneurs persist while others quit. While motivational factors of entrepreneurs are generic worldwide, there are differences that depend on the current situation in local environment (Stefanovića et al., 2011: 79).

Theories of needs maintain that entrepreneurs satisfy needs by being motivated to achieve certain outcomes at work. According to Maslow's hierarchy of needs, people's behaviour is motivated by five basic needs, namely physiological, safety, belongingness, esteem and selfactualisation. Each need is motivational at a time (Jones and George, 2011:406). However, Alderfer proposes three universal categories of needs, including existence, relatedness and growth. Alderfer's needs further differ from Maslow's in that needs at more than one level can be motivational at the same time (Nel et al., 2011:292). Other theories of needs that have been studied include Herzberg's motivator-hygiene theory and McClelland's needs for achievement, affiliation, and power (Jones and George, 2011: 406). Scholars through the years have critiqued all the mentioned needs theories and it must be mentioned that no single theory explains everything.

\section{Position in society}

Different people have different standings in society. This contributes to business success through linking with a number of decision-makers in profit and non-profit organisations, government agencies and institutions (Stefanovic et al., 2010:262). Customers are likely to trust people with a higher societal standing.

\section{Interpersonal skills}

According to Khan and Ahmad (2012:297), interpersonal skills refer to the entrepreneur's ability to motivate, communicate, and build the team. Some of the interpersonal skills identified by authors (Ameen et al., 2015) are communication, self-disclosure, selfmanagement and conflict management. These skills have a positive effect on organisational change and entrepreneurial effectiveness. These are the life skills anentrepreneur uses to communicate and interact with other people. These skills include a variety of social abilities like understanding others, empowering, motivating and directing others (Stefanovic et al., 2010: 262). According to Bonnstetter (2012), a lack of 
interpersonal skills would limit entrepreneurs in that they would relate only to those who share their exact communication style, thereby restricting their ability to convey their goals and vision. Ray (1993) discovered that entrepreneurs with strong interpersonal skills were usually more successful in both their professional and personal lives. Customers will always prefer to support the entrepreneur whom they feel understands them the most. Even when the entrepreneur is not able to meet the needs of a customer a pleasant experience can still be maintained.

\section{Leadership skills}

Leadership skills are increasingly being recognised as important to the business enterprise. Arham et al. (2013: 118) have recognised that entrepreneurs cannot successfully develop new ventures in the absence of effective leadership behaviour. Entrepreneurs need to develop solid leadership behaviour in order to take their enterprises through different times. This may help to ensure that employees stay motivated within the enterprise. A key component of effective leadership is found in the leader's power (Jones and George, 2011).

\section{Approval and support}

Entrepreneurship means one is walking on unsecured terrain without secured income or employment. Therefore, support for entrepreneurs' actions is needed (Stefanovic et al., 2010: 263). For entrepreneurs to be successful they need to be approved by both the people being catered for and the community at large. This approval and support may be shown in many ways to the entrepreneur. For example, approval and support can be shown by buying their products and services which can also be repeated. Support can also come from different agencies in the form of funding of just professional advice. Agencies such as the National Youth Development Agency (NYDA) offer grants to deserving candidates.

\section{Business reputation}

Business reputation may take a long time to build. It can be established through long-term experience in business and through maintaining professional relationships with stakeholders (Stefanovic et al., 2010: 263). Once an entrepreneur is known for providing a service perceived as superior more customers will be attracted.

\section{Education and experience}

In South Africa the Global Entrepreneurship Monitor (GEM) found a positive correlation between opportunity-driven entrepreneurship and education levels in 2013 (Dludla, 2014). Entrepreneurship is now offered as a subject at school and has been expanding as a stand-alone module or a major subject. Informal education also exists among entrepreneurs. Some entrepreneurs have heaped major success despite their non-educational background. Some of these entrepreneurs include Sir Richard Branson (founder of the Virgin group). Some are successful in areas that differ from their educational specialty. Naqvi (2011) support the notion that entrepreneurs with prior experience manage their current organisations with greater success than inexperienced entrepreneurs.

\section{Luck}

The luck factor is an uncontrollable force that can impact both the success and failure of entrepreneurship (usually in hindsight). From research it is clear that luck is not considered as a main factor in entrepreneurial success because entrepreneurs tend to underestimate the role of chance in events (Kahneman and Egan, 2011). It can also be argued that bad luck is often considered the reason for entrepreneurial failure. However, Morris (2012: 12) challenges this with his finding that luck indeed plays a part in the fortunes of an entrepreneur. The impact of the luck factor is therefore very subjective.

\section{Innovation}

Innovation is a significant factor as it has led and continues to lead to the development of many of the world's products. It is also vital as it helps organisations achieve competitive advantage. "Innovation is invariably identified as the key driver of long-term economic growth, competitiveness and a better quality of life" (Moses, et al., 2012:1). A setting, therefore, needs to be created wherein people will be encouraged to innovate. However, it is hard to manage innovation and create a work setting that encourages risk taking (Jones and George, 2011: 62).

\section{Entrepreneurial innovation}

The innovation factor may establish the activities that will take place within an organisation. According to Baregheh et al. (2009:1334), "innovation is the multi-stage process whereby organisations transform ideas into improved products, service or processes in order to advance, compete and differentiate themselves successfully in their marketplace." Similarly, George defines it as the process of (1) creating new or improved services and goods that are sought by customers or (2) developing better ways of producing services and goods (Jones and George, 2011:62). Kotler and Keller go further in that they define innovation as any idea, good or service that someone may perceive as new, regardless of its 
its history (2012: 611). Change is therefore integral to innovation. Such change can range from small incremental improvements to radical breakthroughs.

According to Drucker (2015), innovation is a vital instrument of entrepreneurship. "Entrepreneurship is, therefore, the innovatory process involved in the creation of an economic enterprise based on a new product or service which differs significantly from products or services offered by other suppliers in content or in the way its production is organised or in its marketing" (Curran and Burroughs, 1986). In addition, both entrepreneurship and innovation have need for creativity (Okpara, 2007: 2). Innovation is vital to successful entrepreneurship and today's changing and competitive environment further reinforces this view. An organisation that is not creative and innovative will never survive in the market place (Okpara, 2007:2). Thus, entrepreneurs and enterprises have to constantly be creative and innovative in order to stay relevant to their customers, which is the primary purpose of every business. Successful future entrepreneurs are likely to integrate innovation into their strategic goal.

In 2008 a study was conducted in the Kermanshah province in Iran. The aim was to study factors that determined the success of rural entrepreneurs in the township of Mahidasht where a census of 70 rural entrepreneurs was conducted. The study found that internal factors (such as innovativeness, need for achievement and internal locus of control) and external factors (such as bureaucracy and marketing opportunities) accounted for $88 \%$ of the entrepreneurs' success.

\section{Challenges that confront rural entrepreneurs}

Administrative bureaucracy: Among the factors that hinder entrepreneurship is bureaucracy. In particular, bureaucracy makes it hard for entrepreneurs to stay in business. According to Boshoff (2015), bureaucracy together with intricate 'red tape' remains key element among the hurdles that entrepreneurs and small business owners are faced with currently. One form of bureaucracy involves obtaining finances and can lead to entrepreneurs having to surrender their dreams. Bureaucracy must be reduced by an enabling environment, where small businesses are allowed to trade.

Lack of finances: Ngorora and Mago (2013) found financial constraints as the primary hindering factor for entrepreneurship in the rural area of the Eastern Cape (2013: 1). Finances are vital to entrepreneurship and are the lifeblood of an enterprise (Sharma et al. 2013: 1037). However, obtaining a business's financial support from the bank is actually as difficult. Also, rural entrepreneurs tend to have no tangible security and credit in the market (Sharma et al., 2013: 1037). Due to this lack of sufficient finances, they may not be able to adopt an advertisement strategy for the product and so cannot increase their sales turn-over (Venkateswarlu and Ravindra, 2014: 465). Accordingly, some entrepreneurs resort to obtaining finances from village money lenders. These lenders charge inflated interest amounts. The government should step in where private financial institutions are falling short. Such action by the government will develop rural entrepreneurship which in turn would lead to the economic development of the nation as a whole.

Poor infrastructure: Certain industries, for example the agricultural industry, rely on transportation. The crafts industry also needs a good transportation system for tourists and manufactures to access the market. In many rural areas the transportation system is too poorly developed to properly support sustainable development. According to Mugobo and Ukpere (2012: 832), such challenges include poor road networks, absence of reliable telecommunication and postal services. Another area of poor infrastructure is electricity.

Poor information networks: Entrepreneurship does not mean that contact with people (who may provide the necessary information to the entrepreneur) is readily available. This means the rural entrepreneur may have to rely on other methods of connecting with sources of advice. The role of internet has been growing throughout, but it remains expensive in rural areas. As a result, rural communities are marginalised. For the reason that rural entrepreneurs lack market information, intermediaries may end up taking advantage of them. As a result, networking has become an important tool in that it allows entrepreneurship to fulfil its welfare.

Jones and George (2011: 518) consider competition as a conflict-handling approach which is ineffective where all parties try to maximise their own gain but have little interest in understanding the other party's position and arriving at a solution that allows all parties to attain their goals. In particular, rural entrepreneurs are likely to face severe competition from large-sized organisations and urban entrepreneurs. They incur high production costs due to high cost of input. The major problems faced by marketers are those of standardisation and competition from large-scale units (Das, 2014: 180). Competition from large-scale units also makes it difficult for new ventures to survive. Such new ventures have constrained financial resources and therefore cannot afford to spend a lot on sales promotion. These unit furthermore lack standard brand names under which they can sell their products (Das, 2014: 180). In addition, rural consumers' literacy rate is low (Venkateswarlu and Ravindra, 2014: 464).

\section{METHODOLOGY}

\section{Type of research}

This study uses quantitative research for the reason that it tests objective theories through comparing relationships among variables. The researchers sought to explore the phenomenon of factors and their impact. The outcomes of this research are 
furthermore measurable and quantifiable, which makes the study quantitative in nature.

\section{Sampling method}

Non-probability sampling strategy was used, since the study did not involve random selection. In line with non-probability study, a convenient sampling strategy was used given that it was more convenient and inexpensive. Not every entrepreneur had an equal chance of participating in the study.

In this study the target population was entrepreneurs from Bungeni, a rural area in the Limpopo province in South Africa. Since hundreds of entrepreneurs operate at Bungeni, and the majority have their own informal businesses, it would be very difficult to conduct a study to include all entrepreneurs. For example, additional resources would need to be utilised in order to get all the entrepreneurs to participate.

The study included a sample of 50 entrepreneurs from the target population as this was more manageable. A sample refers to a group of people, objects or items that are taken from a larger population for measurement and should be representative of the population to ensure that the findings from the research sample can be generalised to the population as a whole (Flick, 2015). The findings obtained from the sampled 50 entrepreneurs were generalised to the hundreds of entrepreneurs at Bungeni village.

\section{Questionnaires}

Questionnaires were used as research instruments. Based on the literature review, seventeen factors were used as a measurement instrument. This instrument examined two variables to determine their relationship. The first variable looked at how the importance of these factors was considered for entrepreneurial success while the second variable looked at how they influenced innovation. With reference to the above stated factors, seventeen (17) statements were made and measured according to the five point ordinal scale (Linkert scale), which is 'strongly disagree', 'disagree', 'neutral', 'agree' and 'strongly agree'.

\section{Data analysis}

Schwandt (2014) explains that data analysis is the activity of making sense of, theorising and interpreting data that signifies a search for general statements among categories of data. The onetailed test (t-test) statistical tool was used to process the data and obtain preliminary results. An analysis of the response variables to a categorical analysis of ordinal and nominal data follows and this was presented both descriptively and inferentially.

Descriptive analysis involves summarising data with the purpose of describing what occurred in the sample in such a way that (for example) patterns might emerge from the data (Thompson, 2008:57). Inferential analysis focuses on drawing conclusions about the population on the basis of sample analysis and observation (Neelankavil, 2015). Once the data was collected, it was organised and analysed according to the IBM SPSS 21 analysis system. Tables and charts were designed to present the data.

\section{Validity and reliability}

Validity is concerned with whether researchers actually measure what they intended to measure (Drost, 2011: 114). To achieve this validity, questionnaires contained a variety of questions on the factors that affect entrepreneurial success and how this impacts on innovation, in line with the subject of the literature review. Validity was further ensured by the consistency of administering these questionnaires. The researcher personally distributed all the questionnaires to the respondents. For ease of understanding and for clarity the questions were formulated in a simple language. Clear instructions were offered to the subjects and the researcher offered assistance to those respondents who could not read or understand. All the respondents completed the questionnaires in the presence of the researcher as a way to ensure that the participants completed the questionnaires themselves.

Reliability is "the extent to which measurements are repeatable when different persons perform the measurements, on different occasions, under different conditions, with supposedly alternative instruments which measure the same thing" (Drost, 2011:106). The response yielded was consistent and reliability was further ensured by minimising sources of measurement error such as data collector bias. Data collector bias was minimised in that the researcher was the only person who administered the questionnaires and since the researcher reflected similar personal attributes to that of all the respondents including friendliness and support. The respondents were enabled to be part of a comfortable environment while they completed the questionnaires, which ensured privacy and confidentiality.

\section{RESULTS AND DISCUSSION}

\section{Good management skills}

Good management skills are some of the factors that affect success among entrepreneurs. Thirty-nine percent $(39 \%)$ of the respondents strongly agreed with the statement while $31 \%$ agreed and $15 \%$ disagreed $(10 \%$ strongly disagreed, $5 \%$ disagreed) and $15 \%$ remained neutral. The results of the respondents are in line with Khan and Ahmad's (2012:297) assertion on good management skills for entrepreneurs. According to Khan and Ahmad (2012:297), good management skills have the ability to motivate, communicate, and build a team. Such management skills and have a positive effect on organisational change and entrepreneurship effectiveness. These are the life skills that an entrepreneur uses to communicate and interact with other people. These skills include a variety of social abilities like understanding, empowering, motivating and directing others (Stefanovic et al., 2010: 262) Appendix 1.

\section{Charisma and friendliness}

Fifty-one percent of the respondents strongly agreed and $45 \%$ agreed while $5 \%$ strongly disagreed. These figures cumulatively indicate why a good entrepreneur is an individual who knows he or she is human and who understands the importance of being that way. Friendlynatured people unconsciously surround themselves around positive people and this naturally helps them to build a solid network. The influence of personality traits may be stronger within entrepreneurs than within most other professions (Brandstätter, 2011) Appendix 2. 


\section{Satisfactory government support}

Eighteen percent of the respondents agreed, 18\% strongly agreed and 15\% remained neutral while 33\% disagreed and $15 \%$ strongly disagreed. The response ratio reveals that the respondents fully understand the support government ought to render to entrepreneurs. The response reflects a lack of government support to entrepreneurs. Entrepreneurship contributes to national economies through starting up and running small and medium sized enterprises (SMEs), which could make up to $95 \%$ of the total number of enterprises and which could provide jobs to more than $60 \%$ of all employees within each country (Stefanovića et al., 2011: 79). Government support is therefore a vital factor for entrepreneurial success. Some of the ways the government achieves the above-mentioned objectives include enacting entrepreneur-friendly policies (Obaji and Olugu, 2014: 110).

\section{Access to capital}

The access to capital factor affects entrepreneurial success. Overall, $97 \%$ agreed $(71 \%$ strongly agreeable and $26 \%$ agreeable to the statement) and only $3 \%$ strongly disagreed. Therefore, the lack of capital challenges the growth and development of the entrepreneurial sector. Due to lack of the necessary capital, the owner is the centre of the business, and therefore makes all or most of the decisions in the small business. As a result, an entrepreneur's access to capital depends, to a certain extent; on the support government has put in place (Modimogale and Jan, 2011:4).

\section{Previous business experience and education}

The respondents' previous business experience varied across groups. The results indicate that $23 \%$ strongly agreed, and $41 \%$ agreed and $28 \%$ disagreed. Thus, the real potential for entrepreneurs is informal education, which exists amongst entrepreneurs (Ucbasaran et al., 2010). Levels in entrepreneurship exist where individuals with more education and those from higher income households are more likely to partake in opportunity entrepreneurship. On the other hand, those from lower income households and those with less education pursue necessity entrepreneurship (Venter et al., 2010: 22).

\section{Support of family and friends}

The support of family and friends is a vital aspect for the success of entrepreneurs. Overall, 64\% agreed (33\% strongly agreeable and $31 \%$ agreeable to the statement) and $23 \%$ were disagreeable (15\% disagreed and $8 \%$ strongly disagreed). Thirteen percent remained neutral.
The results show that small business owners need a lot of support to succeed, irrespective of whether this support is financial, operational or emotional. One of the most important sources of this support for many entrepreneurs is their network of friends and family members (Cakula et al., 2013). Emotional support can be similarly important to a small business owner as financial support simply because the stresses that come along with building and growing a business cannot always be solved with money.

\section{Marketing sales and promotions}

The majority of the respondents strongly agreed that the marketing of sales and promotions was a major factor of entrepreneurial success. Eighty-two percent agreed (41\% agreed and $41 \%$ strongly agreed) and 3\% disagreed. Marketing therefore play a key role in business success. Entrepreneurs need to decide which customers to target. They need to work out how to reach and win new customers and they also need to make sure that they keep their existing customers happy.

Firstly, all marketing involves the formulation and implementation of the basic policies which are known as the 4 P's: product, price, place, and promotion. Secondly, international marketing, unlike domestic marketing, transpires to be carried out "across borders". Marketing is about identifying customers' needs and wants in different markets and cultures. In addition, it means providing products, services, technologies and ideas to offer the organisation a competitive marketing advantage. Likewise, it involves imparting information about these products and services and then distributing and exchanging them internationally by one or a combination of the foreign market modes of entry (Kotler and Keller, 2012).

\section{Good customer service}

The majority of the participants agreed that excellent customer service affected the entrepreneur's success (28\% agreed and 64\% strongly agreed) while 3\% remained neutral. According to Gebauer and Fleisch (2007), people are a crucial variable in the entrepreneurial world. The experiences of people who deal directly with your customers clearly differentiates an entrepreneur from his or her competitors. Customer service is about taking care of the customers' needs by providing and delivering not only professional service, but also service that helpful and of high quality. Customer assistance also includes service before, during and after the customer's requirements are met.

\section{Maintenance of accurate records}

The results depicted mixed results as $23 \%$ agreed, $13 \%$ 
strongly disagreed, $31 \%$ disagreed and $28 \%$ remained neutral while $5 \%$ strongly agreed. For most entrepreneurs, maintenance of accurate records for entrepreneurs was the least fun part of the job. When managing a growing business, it is often tempting to ignore some of the administrative formalities in order to stay focused on sales, customer satisfaction and new product development. However, while staying on top of the business, the maintenance of accurate records for entrepreneurs becomes essential for both legal and strategic reasons (Penn, Pennix and Coulson, 2016).

\section{Ability to manage personnel}

The statement attracted mixed responses as $18 \%$ strongly agreed, $36 \%$ agreed, $28 \%$ disagreed and $18 \%$ remained neutral. The ability to manage personnel is probably the most important trait or skill required for entrepreneurship. According to Barba-Sánchez and Atienza-Sahuquillo (2012), successful entrepreneurs must have the managerial skills necessary to evaluate potential employees, hire and train workers and put them in appropriate positions in the organisation. This means being a good judge of character, finding people who will work well together and ensuring that staffers are qualified for their jobs. Once employees are on the job, a successful entrepreneur must be able to manage teams, oversee conflict, dispute resolution, and provide ongoing training to encourage high-quality performance.

\section{CONCLUSION AND RECOMMENDATIONS}

A closer look into the results reveals that environmental and demographic factors affect success among entrepreneurs. A hosts of environmental factors impede the success of entrepreneurs in Limpopo. For example, Singh-Sandhu et al (2011) reported a lack of government support and incentives. Several studies (Williams and Williams, 2011; Fatoki and Patswawairi, 2012; Webb et al., 2013) also reported on the absence of appropriate support.

The current study established that bureaucratic obstacles such asaccess to capital, political involvement and satisfactory government support are some of the challenges that entrepreneurs face in their quest to starting and maintaining a business. A host of factors are identified, including lack of long-term capital (Chowdhury and Amin 2011); limited friendly and family support (Mahajan, 2013); limited access to marketing and sales promotions; lack ofprevious business experience (Sumra et al., 2011; Clarysse et al., 2011; Samuel, Ernest and Awuah, 2013); technology (Duru, 2011; Griskevicius et al., 2012); and lack of information (Kozlinska, 2011; Preisendörfer et al., 2012). These factors have been found as impeding to the success of entrepreneurs in Limpopo. The foregoing discussion thus reveals that entrepreneurial success is influenced by environmental factors. The following recommendations are suggested to enhance entrepreneurial success:

(i) The government, society, and particularly private organisations, need to be more supportive to the activities of entrepreneurs.

(ii) In Limpopo, entrepreneurs require appropriate entrepreneurial training so that they can experience greater success and hence avoid obvious the mistakes that other entrepreneurs make.

(iii) Local consumers must be encouraged to support local entrepreneurs by transacting with them.

(iv) Local entrepreneurs should participate in social initiatives that are aimed at uplifting communities.

\section{CONFLICT OF INTERESTS}

The authors have not declared any conflict of interests.

\section{REFERENCES}

Amiri N, Marimaei M (2012). Concept of entrepreneurship and entrepreneurs traits and characteristics. Scholarly Journal of Business Administration 2(7):150-155.

Arham A, Boucher C, Muenjohn N (2013). Leadership and entrepreneurial success: A study of SMEs in Malaysia. World 3(5):117-130.

Ashenbaum B, Salzarulo P, Newman W (2012). Organizational structure, entrepreneurial orientation and trait preference in transportation brokerage firms. Journal of Supply Chain Management 48(1):3-23.

Asoni A (2011). Intelligence, Self-confidence and Entrepreneurship. RIIE, IFN Working Paper No. 887, 2011.

Barba-Sánchez V, Atienza-Sahuquillo C (2012). Entrepreneurial behavior: Impact of motivation factors on decision to create a new venture. Investigaciones Europeas de Dirección y Economía de la Empresa 18(2):132-138.

Baregheh A, Rowley J, Sambrook S (2009). Towards a multidisciplinary definition of innovation. Management Decision 47:1323-1339.

Bonnstetter B (2012). New Research: The Skills That Make an Entrepreneur. Available at: https://patrickspannfoundation.org/wpcontent/uploads/2016/03/New-Research_-The-Skills-That-Make-anEntrepreneur.pdf

Boshoff T (2015). Bureaucracy a barrier to entrepreneurship. Mail and Guardian. 30 October 2015. Available at:

https://mg.co.za/article/2015-10-30-00-bureaucracy-a-barrier-toentrepreneurship

Brandstätter H (2011). Personality aspects of entrepreneurship: A look at five meta-analyses. Personality and Individual Differences 51(3):222-230.

Brundin E, Gustafsson V (2013). Entrepreneurs' decision making under different levels of uncertainty: the role of emotions. International Journal of Entrepreneurial Behavior and Research 19(6):568-591.

Cakula S, Jakobsone A, Motejlek (2013). Virtual business support infrastructure for entrepreneurs. Procedia Computer Science 25:281288.

Carland J, Carland J (2015). A model of potential entrepreneurship: Profiles and educational implications. Journal of Small Business Strategy 8(1):1-14.

Chowdhury M, Amin M (2011). The effects of human, social, and financial capital on the woman entrepreneurship venturing in Bangladesh. International Journal of Business and Economics Perspectives 6(1):138-150.

Clarysse B, Tartari V, Salter A (2011). The impact of entrepreneurial 
capacity, experience and organizational support on academic entrepreneurship. Research Policy 40(8):1084-1093.

Covin J, Wales W (2011). The measurement of entrepreneurial orientation. Entrepreneurship Theory and Practice 36(4):677-702.

Cubico S, Bortolani E, Favretto G, Sartori R (2010). Describing the entrepreneurial profile: the entrepreneurial aptitude test (TAl). International Journal of Entrepreneurship and Small Business $11(4): 424-435$.

Currie $\mathrm{G}$ (2008). Entrepreneurial leadership in the English public sector: paradox or possibility?. Public Administration 86(4):987-1008.

Das D (2014). Prospects and Challenges of Rural Entrepreneurship Development in NER-A Study. Assam: International Journal of Humanities and Social Science Studies 1(2):178-182.

Dess GG, Lumpkin GT, Eisner AB (2014). Strategic management: Text and cases. McGraw-Hill Education.

Dludla S (2014). Does your level of education determine entrepreneurial success? A look at the impact of schooling on entrepreneurs' potential to succeed. SME South Africa. Available at: https://www.smesouthafrica.co.za/Does-your-level-of-educationdetermine-entrepreneurial-success/

Donatelle R (2011). Health: The basics (Green ed.). San Francisco: Pearson Benjamin Cummings.

Drost E (2011). Validity and Reliability in Social Science Research. Education Research and Perspectives 38(1):105-123.

Drucker P (2015). Innovation and Entrepreneurship. London and New York: Routledge. Available at: https://www.taylorfrancis.com/books/9781317601364

Duru M (2011). Entrepreneurship opportunities and challenges in Nigeria. Business and Management Review 1(1):41-48.

EL-Annan S (2013). Innovation, proactive, and vision are three integrated dimensions between leadership and entrepreneurship. European Journal of Business and Social Sciences 1(12):148-163.

Fatoki O, Patswawairi T (2012). The motivations and obstacles to immigrant entrepreneurship in South Africa. Journal of Social Sciences 32(2):133-142.

Flick U (2015). Introducing Research Methodology: A Beginner's Guide to Doing a Research Project. California: SAGE publications.

Friedman B (2011). The relationship between governance effectiveness and entrepreneurship. International Journal of Humanities and Social Science 1(17):221-225.

Gatewood EJ, Shaver KG, Gartner WB (1995). A longitudinal study of cognitive factors influencing start-up behaviors and success at venture creation. Journal of Business Venturing 10(5):371-391.

Gebauer H, Fleisch E (2007). An investigation of the relationship between behavioral processes, motivation, investments in the service business and service revenue. Industrial Marketing Management 36(3):337-348.

Gordon S, Tarafdar M, Cook R, Maksimoski R, Rogowitz B (2008). Improving the front end of innovation with information technology. Research-Technology Management 51(3):50-58.

Greathouse J (2011). Entrepreneurs Need The Confidence, Courage And Conviction To Be Unreasonable. Business Insider. Available at: https://www.businessinsider.com/entrepreneurs-need-the-confidencecourage-and-conviction-to-be-unreasonable-2011-8? IR=T

Gries T, Naudé W (2011). Entrepreneurship and human development: A capability approach. Journal of Public Economics 95(3-4):216-224.

Griskevicius V, Cantú SM, Vugt MV (2012). The evolutionary bases for sustainable behavior: Implications for marketing, policy, and social entrepreneurship. Journal of Public Policy and Marketing 31(1):115128.

Hornaday JA, Bunker CS (1970). The nature of the entrepreneur. Personnel Psychology 23(1):47-54.

Ihugba O, Odii A, Njoku A (2014). Theoretical analysis of entrepreneurship challenges and prospects in Nigeria. International Letters of Social and Humanistic Sciences 5:21-34.

lyigun NO (2015). What could entrepreneurship do for sustainable development? A corporate social responsibility-based approach. Procedia-Social and Behavioral Sciences 195:1226-1231.

Jones G, George J (2011). Contemporary Management. $7^{\text {th }}$ Edition. New York: McGraw-Hill Irwin. Available at: https://trove.nla.gov.au/work/4053759?q\&sort=holdings+desc\&_=153 $9255892249 \&$ versionld $=48626375+165446817$
Kahneman D, Egan P (2011). Thinking, fast and slow (Vol. 1). New York: Farrar, Straus and Giroux.

Khan A, Ahmad W (2012). Leader's interpersonal skills and its effectiveness at different levels of management. International Journal of Business and Social Science 3(4):296-305.

Kotler P, Keller K (2012). Marketing Management. $14^{\text {th }}$ Edition. Essex: Pearson.

Kozlinska I (2011). Contemporary approaches to entrepreneurship education. Journal of Business Management 4(1):205-220.

Klubeck M (2017). Success Metrics: A Multidimensional Framework for Measuring Organizational Success. Michigan: Apress. Available at: https://www.apress.com/us/book/9781484225851

Kraus S, Rigtering J, Hughes M, Hosman V (2012). Entrepreneurial orientation and the business performance of SMEs: a quantitative study from the Netherlands. Review of Managerial Science 6(2):161-182.

Kritikos $A$ (2014). Entrepreneurs and their impact on jobs and economic growth. IZA world of labor. Berlin, Germany. Available at: https://wol.iza.org/articles/entrepreneurs-and-their-impact-on-jobsand-economic-growth/long

Lumpkin GT, Dess GG (1996). Clarifying the entrepreneurial orientation construct and linking it to performance. Academy of management Review 21(1):135-172.

Mahajan S (2013). Women entrepreneurship in India. Global Journal of Management and Business Studies 3(10):1143-1148.

Mastura JA, Rashid AA, Rozlinda AL (2009). Entrepreneurial characteristics of indigenous housing developers: the case of Malaysia. Economia Seria Management 12(2):73-91.

Modimogale L, Jan $\mathrm{H}$ (2011). The role of ICT within small and medium enterprises in Gauteng. Communications of the IBIMA pp. 1-9.

Morris $M$ (2012). A practical guide to entrepreneurship: how to turn an idea into a profitable business. Kogan Page Publishers.

Moses C, Sithole M, Blankley W, Labadarios D, Makelane H, Nkobole N (2012). The state of innovation in South Africa: Findings from the South African National Innovation Survey. South African Journal of Science 108(7-8):15-20.

Mugobo V, Ukpere W (2012). Rural entrepreneurship in the Western Cape: Challenges and opportunities. African Journal of Business Management 6(3):827-836.

Neelankavil J (2015). International Business Research. New York: Routledge.

Nel P, Werner A, Poisat P, Sono T, Du Plessis A, Ngalo O, Van Hoek L, Botha C (2011). Human Resource Management. $3^{\text {rd }}$ Edition. Cape Town: Oxford.

Ngorora GPK, Mago S (2013). Challenges of rural entrepreneurship in South Africa: insights from nkonkobe municipal area in the Eastern Cape Province. International Journal of Information Technology and Business Management 16(1):1-11.

Ngek N, and van Aardt Smit A (2013). Will promoting more typical SME start-ups increase job creation in South Africa? African Journal of Business Management 7(31):3043-3051.

Northouse PG (2013). Leadership: Theory and practice (6th Edition). Thousand Oaks, CA: Sage. Avaialable at https://www.amazon.com/Leadership-Practice-Peter-GNorthouse/dp/8132110072

Obaji N, Olugu M (2014). The role of government policy in entrepreneurship development. Science Journal of Business and Management 2(4):109-115.

Okpara FO (2007). The value of creativity and innovation in entrepreneurship. Journal of Asia Entrepreneurship and Sustainability $3(2): 1-14$

Olakitan OO, Ayobami AP (2011). An investigation of personality on entrepreneurial success'. Journal of Emerging Trends in Economics and Management Sciences 2(2):95-103.

Penn I, Pennix G, Coulson J (2016). Records Management Handbook. New York: Routledge.

Provincial Review (2016). The Real Economy Bulletin: Trends Developments and Data. Available at http://www.tips.org.za/manufacturing-data/the-real-economybulletin/provincial-review/item/3172-the-real-economy-bulletinprovincial-review-2016

Ray D (1993). Understanding the entrepreneur: entrepreneurial 
attributes, experience and skills. Entrepreneurship and Regional Development 5(4):345-358.

Samuel Y, Ernest K, Awuah J (2013). An assessment of entrepreneurship intention among Sunyani Polytechnic Marketing students. International Review of Management and Marketing, $3(1): 37-49$.

Schillo R (2011). Entrepreneurial Orientation and Company Performance: Can the Academic Literature Guide Managers? Technology Innovation Management Review 1(2):20-25.

Sexton D, Bowman N (1985). The entrepreneur: A capable executive and more. Journal of Business Venturing 1(1):129-140.

Sharma M, Chaudhary V, Bala R, Chauhan R (2013). Rural entrepreneurship in developing countries: Challenges, problems and performance appraisal. Global Journal of Management and Business Studies 3(9):1035-1040.

Singh-Sandhu M, Fahmi-Sidique S, Riaz S (2011). Entrepreneurship barriers and entrepreneurial inclination among Malaysian postgraduate students. International Journal of Entrepreneurial Behavior and Research 17(4):428-449.

Smith C (2016). Tshwane beats Jozi, CT in highest per capita personal income. Available at: https://www.fin24.com/Economy/tshwanebeats-jozi-ct-in highest-per-capita-personal-income-20160808

Stats SA (2017). Statistical Release: Quarterly Labour Force Survey. Pretoria. Available http://www.statssa.gov.za/publications/P0211/P02113rdQuarter2017. pdf

Stefanovic I, Prokic S, Rankovic L (2010). Motivational and success factors of entrepreneurs: the evidence from a developing country. Available at: https://hrcak.srce.hr/file/93452.html

Stefanovića I, Rankovićb L, Prokićc S (2011). Entrepreneurs' motivational factors: Empirical evidence from Serbia. Serbian Journal of Management 6(1):73-83.

Stoycheva K (2010). Tolerance for ambiguity, creativity, and personality. Bulgarian Journal of Psychology (1-4):178-188.

Sumra SH, Safarish H, Suhail S, Ahmad ST (2011). Factors responsible for low inclination towards Entrepreneurship in the public sector institutions of Pakistan. Journal of Public Administration and Governance 1(1):75-105.

Naqvi SWH (2011). Critical success and failure factors of entrepreneurial organizations: Study of SMEs in Bahawalpur. Journal of Public Administration and Governance 1(2):17-23.
Talebi K, Nouri P, Kafeshani A (2014). What Factors Contribute to Entrepreneursâ€ $€^{\mathrm{TM}}$ Decision Making Biases? A Comprehensive Study. International Journal of Management Sciences 4(2):59-68.

Thompson C (2008). Descriptive data analysis. Air Medical Journal 28(2):56-59.

Tomaa S, Grigore A, Marinescu P (2014). Economic development and entrepreneurship. Procedia Economics and Finance 8:436-443.

Ucbasaran D, Westhead P, Wright M, Flores M (2010). The nature of entrepreneurial experience, business failure and comparative optimism. Journal of Business Venturing 25(6):541-555.

Venkateswarlu P, Ravindra P (2014). An Empirical Study on Problem and Prospects of Rural Entrepreneurs with Special Reference to Visakhapatnam District. International Journal of Management and Commerce Innovations 2(2):458-467.

Venter R, Urban B, Rwigema H (2010). Entrepreneurship: Theory in practice. $2^{\text {nd }}$ Edition. Cape Town: Oxford.

Webb W, Bruton D, Tihanyi L, Ireland D (2013). Research on entrepreneurship in the informal economy: Framing a research agenda. Journal of Business Venturing 28(5):598-614.

Wiklund J, Shepherd D (2003). Knowledge-based resources, entrepreneurial orientation, and the performance of small and medium-sized businesses. Strategic Management Journal 24(13):1307-1314.

Williams N, Williams C (2011). Tackling barriers to entrepreneurship in a deprived urban neighbourhood. Local Economy 26(1):30-42. 
ANNEXURE A: QUESTIONNAIRE Appendix 1 Success Variables for Entrepreneur

\begin{tabular}{|c|c|c|c|c|c|}
\hline Success variables & Strongly disagree & Disagree & Neutral & Agree & Strongly agree \\
\hline \multicolumn{6}{|l|}{ 1. Good management skills } \\
\hline \multicolumn{6}{|l|}{ 2. Charisma: friendliness } \\
\hline \multicolumn{6}{|c|}{ 3. Satisfactory government support } \\
\hline \multicolumn{6}{|c|}{ 4. Appropriate training } \\
\hline \multicolumn{6}{|l|}{ 5. Access to capital } \\
\hline \multicolumn{6}{|c|}{ 6. Previous business experience } \\
\hline \multicolumn{6}{|c|}{ 7. Support of family and friends } \\
\hline \multicolumn{6}{|c|}{ 8. Marketing/sales promotion } \\
\hline \multicolumn{6}{|c|}{ 9. Good product at competitive price } \\
\hline \multicolumn{6}{|c|}{ 10. Good customer service } \\
\hline \multicolumn{6}{|l|}{ 11. Hard work } \\
\hline \multicolumn{6}{|c|}{ 12. Position in society } \\
\hline \multicolumn{6}{|c|}{ 13. Maintenance of accurate records } \\
\hline \multicolumn{6}{|c|}{ 14. Ability to manage personnel } \\
\hline \multicolumn{6}{|c|}{ 15. Social skills } \\
\hline \multicolumn{6}{|l|}{ 16. Political involvement } \\
\hline \multicolumn{6}{|l|}{ 17. Reputation for honesty } \\
\hline Other & & & & & \\
\hline
\end{tabular}

Mark with X.

Source: Stefanovic et al. (2010).

\section{Appendix 2 Impact of Innovation on Entrepreneur}

\begin{tabular}{lll}
\hline & Impact on innovation & \\
\hline Success variables & Optimises innovation & Neutral \\
\hline 1. Good management skills & \\
2. Charisma: friendliness & \\
3. Satisfactory government support & \\
4. Appropriate training \\
5. Access to capital \\
6. Previous business experience \\
7. Support of family and friends \\
8. Marketing/sales promotion \\
9. Good product at competitive price \\
10. Good customer service \\
11. Hard work \\
12. Position in society \\
13. Maintenance of accurate records \\
14. Ability to manage personnel \\
15. Social skills \\
16. Political involvement \\
17. Reputation for honesty \\
Other
\end{tabular}

Source: Stefanovic et al. (2010). 